JAMP: Jurnal Adminitrasi dan Manajemen Pendidikan Volume 1 Nomor 3 September 2018, Hal : 270-278

Tersedia Online di http://journal2.um.ac.id/index.php/jamp/ ISSN 2615-8574 (online)

\title{
PROSES PERUBAHAN \\ STATUS MADRASAH SWASTA MENJADI MADRASAH NEGERI
}

\author{
Ahmad Tohirin \\ Mustiningsih \\ Sultoni \\ ahmadtohirin214@gmail.com \\ Universitas Negeri Malang, Jl. Semarang No. 5 Malang 65145
}

\begin{abstract}
This study aims to describe (1) the base of change of madrasah status, (2) the change process of madrasah status, (3) the arrangement of teachers and administrative staff after becoming a public madrasah, (4) infrastructure administration, and (5) impacts of the change. This study used qualitative approach with a case study design. Results indicate that the base of changes in the status, the change process in the school status influenced organizational aspects including teachers, administrative staff and facilities.
\end{abstract}

Keywords: change process, organizational madrasah status

\begin{abstract}
Abstrak: Penelitian ini bertujuan untuk mendeskripsikan (1) dasar pelaksanaan perubahan status madrasah, (2) proses pelaksanaan perubahan status madrasah, (3) penataan guru dan tenaga kependidikan setelah menjadi madrasah negeri, (4) penataan sarana dan prasarana, dan (5) dampak perubahan status madrasah. Penelitian ini menggunakan pendekatan kualitatif dengan jenis penelitian studi kasus. Hasil penelitian ini menunjukkan dasar perubahan status madrasah, proses sekaligus berdampak pada aspek-aspek perubahan lainnya yaitu guru, tenaga kependidikan, sarana dan prasarana.
\end{abstract}

Kata Kunci: proses perubahan, status organisasi madrasah

Perubahan merupakan suatu hal yang tidak dapat dihindari. Perubahan dalam dunia manajemen dialami oleh organisasi akibat beberapa faktor pendorong baik secara eksternal maupun internal. Sekolah sebagai organisasi akan menghadapi tantangan-tantangan perubahan. Tanpa perubahan yang memadai suatu organisasi tidak akan bertahan lama. Perubahan yang dimaksud merupakan pergeseran dari keadaan sekarang suatu organisasi menuju pada keadaan yang diinginkan di masa yang akan datang guna meningkatkan efektivitas dan efisiensi. Sesuai yang dikemukakan oleh Winardi (2005: 2) "perubahan keorganisasian (organizational changed) merupakan tindakan beralihnya suatu organisasi dari kondisi yang berlaku kini, menuju ke kondisi masa yang akan datang yang diinginkan guna meningkatkan efektivitasnya". Lembaga dan sumber daya yang terkait harus dapat menyesuaikan diri agar mereka dapat menjaga eksistensinya. Untuk dapat melakukan suatu perubahan, organisasi perlu melihat kondisi lingkungan di sekitarnya, sebagai kekuatan yang mempengaruhi strategi organisasi dalam jangka panjang. Stoner, dkk (dalam Supriyanto 2009:12), mengemukakan bahwa "secara umum organisasi memiliki lingkungan internal dan eksternal. Lingkungan internal meliputi pegawai, pemegang saham, dan dewan direksi. Sedangkan pada lingkungan eksternal terdapat pelanggan, pemasok, pemerintah, kelompok khusus, media, serikat kerja, lembaga keuangan, dan pesaing". Melihat hal tersebut lingkungan baik internal maupun eksternal dapat mempengaruhi sebuah organisasi dan siapa saja yang terkait di dalamnya. 
Organisasi pendidikan merupakan sarana masyarakat untuk dapat maju dan berkembang seiring perkembangan Ilmu Pengetahuan dan Teknologi (IPTEK) yang saat ini semakin pesat. Pendidikan berperan penting terhadap perkembangan suatu bangsa. Berbagai strategi dilakukan untuk menciptakan sistem pendidikan yang memenuhi tuntutan perkembangan jaman. Sejarah perkembangan dunia pendidikan di Indonesia telah menegaskan bahwa pendidikan madrasah terbukti memberikan andil yang cukup besar bagi terwujudnya upaya mencerdaskan kehidupan bangsa dan negara melalui penyiapan dan perkembangan sumber daya manusia Indonesia yang kuat dan berkualitas, baik secara fisik, mental maupun spiritual. Keberadaan madrasah telah mengakar kuat di masyarakat dan berkembang bersamaan dengan dinamika perjalanan bangsa. Munculnya Undang-undang Sistem Pendidikan Nasional nomor 20 tahun 2003 yang secara tegas mengakui eksistensi pendidikan madrasah sebagai bagian yang tak terpisahkan dari sistem pendidikan nasional, telah membuka peluang lebar bagi upaya pengembangan madrasah sebagai lembaga pendidikan yang kompetitif, kapabel dan memiliki hak dan tanggung jawab yang sama dengan sekolah. Tentu sudah sepatutnya pemerintah memberikan perhatian dan pelayanan yang sama bagi upaya apapun yang mengarah pada tercapainya pengembangan mutu pendidikan di madrasah. Termasuk upaya strategis yang dinilai masih perlu dilakukan adalah program penegerian atau perubahan status madrasah.

Menurut Peraturan Menteri Agama Nomor 14 Tahun 2014 tentang pendirian madrasah yang diselenggarakan oleh pemerintah dan penegerian madrasah yang diselenggarakan oleh masyarakat menjelaskan bahwa penegerian madrasah yang diselenggarakan oleh masyarakat yang selanjutnya disebut Penegerian Madrasah adalah kegiatan peralihan status Raudlatul Athfal (RA), Madrasah Ibtidaiyah (MI), Madrasah Tsanawiyah (MTs), Madrasah Aliyah (MA), dan Madrasah Aliyah Kejuruan (MAK) dari status yang diselenggarakan oleh masyarakat menjadi status yang diselenggarakan oleh pemerintah. Upaya perubahan status madrasah adalah dalam rangka meningkatkan mutu lembaga pendidikan tetap dianggap sebagai suatu kebutuhan penting. Terutama tatkala dikaitkan dengan terbatasnya keterlibatan masyarakat dalam pembangunan madrasah secara fisik karena minimnya dukungan finansial. Dengan dinegerikannya sebuah madrasah swasta, implikasinya madrasah menjadi milik negara, dibiayai oleh negara secara bertahap, diatur dan dikelola oleh pemerintah, karena menegerikan madrasah berarti menyerahkan aset madrasah kepada negara untuk dilanjutkan pengelolaannya oleh pemerintah.

Beberapa daerah di Indonesia telah melakukan perubahan status madrasah, seperti halnya yang terjadi di Kabupaten Malang. Pada 2009 pemerintah melakukan penyeleksian berdasarkan persyaratanpersyaratan yang telah ditentukan sebelumnya. Penyeleksian tersebut dilakukan untuk kemudian ditetapkan madrasah-madrasah yang layak untuk dinegerikan. Madrasah tersebut salah satunya yaitu MA Miftahul Huda Turen (sekarang MAN 2 Malang).

\section{METODE}

Pendekatan yang digunakan adalah penelitian kualitatif. Metode penelitian ini digunakan untuk menggali informasi secara mendalam terhadap fenomena mengenai perubahan status madrasah swasta menjadi negeri yang terjadi di MAN 2 Malang. Sedangkan desain jenis penelitian yang digunakan adalah studi kasus karena akan mendeskripsikan dan menganalisis secara mendalam tentang suatu lembaga. Melalui jenis penelitian studi kasus akan bisa mengungkap suatu fenomena secara terfokus dan mendalam. Dalam hal ini, peneliti akan mengungkap suatu peristiwa yang terjadi di MAN 2 Malang, yakni proses perubahan status madrasah swasta menjadi negeri.

Dalam penelitian ini peneliti berperan sebagai instrumen kunci yaitu secara langsung terjun ke lapangan untuk mengumpulkan data. Sumber data dalam penelitian ini terdiri dari tiga orang guru, satu tenaga kependidikan, satu siswa, dua orang komite, dan satu warga sekitar madrasah. Sementara itu, untuk instrumen kunci dalam penelitian ini yaitu Kepala Madrasah yang saat pelaksanaan perubahan berperan sebagai agen perubahan. Kepala Madrasah saat ini menjabat sebagai guru di MAN 2 Malang.

Pengumpulan datayang digunakan peneliti meliputiteknik wawancara, pengamatan dan dokumentasi. Analisis data dalam penelitian ini dilakukan dengan tiga langkah yaitu reduksi data, display data, dan verifikasi data. Dalam analisis data, peneliti mereduksi data yang didapatkan kemudian memilah setiap 
data sesuai dengan fokus dan dilanjutkan membuat kesimpulan pada masing-masing temuan. Setelah proses analisis data maka dilanjutkan dengan pemeriksaan keabsahan temuan informasi menggunakan teknik triangulasi (sumber dan metode/ teknik), perpanjangan waktu pengamatan, pengecekan anggota, dan kecukupan bahan referensi.

\section{HASIL}

\section{Dasar Pelaksanaan Perubahan Status Madrasah Swasta Menjadi Negeri di MAN 2 Malang}

Perubahan status madrasah dilaksanakan berdasarkan Surat Keputusan Nomor 49 Tahun 2009 tentang penetapan 59 (lima puluh sembilan) Madrasah Aliyah Negeri. Adapun ide dasar dilakukannya perubahan status madrasah di MAN 2 Malang adalah pertama karena di wilayah Kecamatan Turen belum ada madrasah aliyah yang berstatus negeri. Kedua, meningkatkan daya saing antar sekolah di Kecamatan Turen. Ketiga, kondisi finansial madrasah yang kurang memadai.

\section{Proses Pelaksanaan Perubahan Status Madrasah Swasta Menjadi Negeri di MAN 2 Malang}

Proses pelaksanaan perubahan status madrasah yang pertama adalah tahap perencanaan yaitu Kepala MAN 2 Malang mengadakan rapat bersama guru, pengurus, dan tokoh masyarakat. Pertemuan ini dimaksudkan untuk membahas teknis pelaksanaan perubahan. Kedua, melengkapi persyaratan yang telah ditentukan. Dilanjutkan dengan pengajuan proposal kepada Kementerian Agama di tingkat Kabupaten, Provinsi, dan Dirjen Pendidikan Madrasah. Dirjen Pendidikan Madrasah kemudian melaksanakan verifikasi kelengkapan persyaratan perubahan masing-masing madrasah yang berminat mengikuti perubahan status. Setelah itu Surat Keputusan status madrasah sudah bisa diterbitkan. Tahap ketiga madrasah memantau perkembangan proses perubahan status tersebut. Tahap terakhir adalah pembakuan, madrasah yang berstatus baru mengadakan program launching penegerian, mengganti stempel dan kop surat menyurat, papan nama madrasah, penugasan pemimpin baru oleh Kepala Kementerian Agama Kabupaten, dan madrasah memperoleh 3 orang guru DPK.

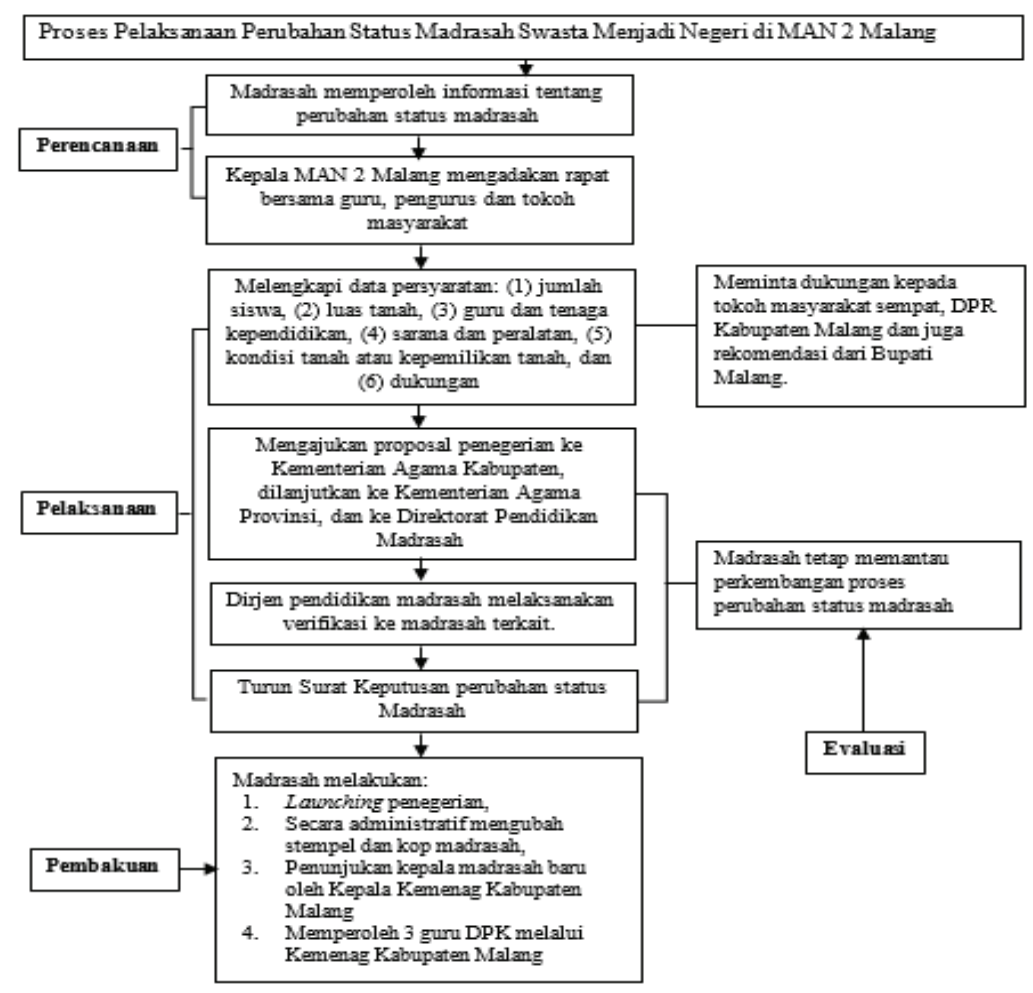

Gambar Proses Pelaksanaan Perubahan Status Madrasah Swasta Menjadi Negeri di MAN 2 


\section{Penataan Status Madrasah Terhadap Guru dan Tenaga Kependidikan di MAN 2 Malang}

Penataan status guru dan tenaga kependidikan baru tidak mengalami perubahan. Perubahan pada guru hanya intensitas pelatihan menjadi lebih tinggi dan SK tugas guru. Untuk tenaga kependidikan yang sebelumnya berkualifikasi SMA sekarang sudah cukup banyak yang meraih level S1. Kedua, sebagian berganti profesi menjadi guru. Ketiga, demikian juga intensitas pelatihan untuk tenaga kependidikan ini menjadi lebih tinggi.

\section{Penataan Sarana dan Prasarana Setelah Menjadi MAN 2 Malang}

Penataan sarana dan prasarana lebih pada pasca perubahan lokasi madrasah. Lokasi MAN 2 Malang sebelumnya berada di jalan Kauman Nomor 18 Turen, sekarang pindah ke jalan Mayor Damar Nomor 35 Pagedangan Kecamatan Turen. Kedua lokasi ini merupakan hasil wakaf dari masyarakat. Gedung lama ditempati oleh MIPN Miftahul Huda Turen. Faktor penunjang perpindahan lokasi adalah tempat yang luas dan lokasi yang nyaman karena jauh dari keramaian. Adapun faktor penghambat bahwasanya pemborong bangunan yang tidak bertanggungjawab sehingga proses pembangunan gedung baru sempat terhenti.

\section{Dampak Perubahan Status Madrasah Setelah Menjadi MAN 2 Malang}

Perubahan status madrasah di MAN 2 Malang berdampak positif maupun negatif. Dampak positif dirasakan oleh berbagai pihak seperti, (a) madrasah, semakin bertambahnya peserta didik, sarana dan prasarana, dan madrasah lebih dikenal oleh masyarakat; (b) guru, bertambahnya pengalaman dan wawasan guru dalam mengajar; (c) siswa, prestasi lebih meningkat dan mereka merasa bangga karena bersekolah di madrasah yang berstatus negeri; (d) pengurus, meringankan beban yayasan dari segi finansial, tidak merasa khawatir akan matinya madrasah swasta, dan hilangnya tanggungjawab terhadap Wakif (pihak yang mewakafkan tanah); dan (e) masyarakat, perekonomian menjadi lebih meningkat. Peningkatan tersebut dikarenakan adanya toko dan pondok pesantren yang semakin berkembang. Sedangkan dampak negatif dari perubahan status adalah secara finansial pengurus merasa kehilangan atas kepemilikan sarana dan prasarana yang diambil alih oleh pemerintah.

\section{PEMBAHASAN}

\section{Dasar Pelaksanaan Perubahan Status Madrasah Swasta Menjadi Negeri di MAN 2 Malang}

MAN 2 Malang dahulu bernama MA Miftahul Huda Turen. Madrasah ini merupakan satu-satunya di Kecamatan Turen yang berubah status. Perubahan didasari atas inisiatif dari dewan guru, komite, pengurus, dan tokoh masyarakat. Berdasarkan hasil penelitian ditemukan bahwa dasar dilaksanakannya perubahan dibagi menjadi 2 yakni, dasar hukum dan dasar ide. Dasar hukum yaitu berdasarkan Surat Keputusan Nomor 49 Tahun 2009 tentang penetapan 59 (lima puluh sembilan) Madrasah Aliyah Negeri. Dasar ide meliputi, pertama karena di wilayah Kecamatan Turen belum ada madrasah aliyah yang berstatus negeri. Kedua, meningkatkan daya saing antar sekolah di Kecamatan Turen. Dan ketiga, dari segi finansial madrasah yang kurang memadai. Hal ini sesuai dengan yang di jelaskan pada Pedoman Pelaksanaan Kegiatan Penegerian Madrasah menurut Direktorat Jenderal Pendidikan Islam (2007: 2) "upaya menegerikan madrasah adalah dalam rangka meningkatkan mutu lembaga pendidikan tetap dianggap sebagai suatu kebutuhan penting. Terutama tatkala dikaitkan dengan terbatasnya keterlibatan masyarakat dalam pembangunan madrasah secara fisik karena minimnya dukungan finansial".

Hasil temuan menunjukkan bahwa tujuan pelaksanaan perubahan status madrasah adalah dalam rangka untuk meningkatkan mutu pendidikan Madrasah Aliyah Swasta di Indonesia. Selain itu juga agar madrasah lebih maju dan terus berkembang, di mana madrasah akan tetap hidup dan lebih baik dari tahun-tahun sebelumnya. Hal ini sesuai dengan yang di jelaskan pada Pedoman Pelaksanaan Kegiatan Penegerian Madrasah menurut Direktorat Jenderal Pendidikan Islam (2007: 7) yaitu "secara umum 
pelaksanaan kegiatan penegerian madrasah memiliki tujuan meningkatkan kualitas penyelenggaraan dan pelayanan pendidikan madrasah supaya lebih maju, mandiri, profesional dan memiliki daya saing global".

\section{Proses Pelaksanaan Perubahan Status Madrasah Swasta Menjadi Negeri di MAN 2 Malang}

Temuan penelitian menunjukkan bahwa proses perencanaan perubahan dimulai dengan Kepala MAN 2 Malang mendapatkan informasi dari Kementerian Agama Kabupaten. Informasi tersebut kemudian ditindaklanjuti dengan mengadakan rapat bersama guru, pengurus dan tokoh masyarakat. Pertemuan ini dimaksudkan untuk membahas teknis pelaksanaan perubahan. Pelaksanaan perubahan perlu melengkapi persyaratan yang telah ditentukan. Persyaratan tersebut di antaranya yaitu: jumlah siswa, luas tanah, guru dan tenaga kependidikan, sarana dan peralatan, kondisi tanah atau kepemilikan tanah, dan dukungan. Temuan ini jika ditinjau dari Pedoman Pelaksanaan Kegiatan Penegerian Madrasah menurut Direktorat Jenderal Pendidikan Islam (2007: 11-15) yang menyebutkan bahwa kriteria dan komponen penegerian madrasah melalui berbagai pertimbangan: (1) kondisi daerah; (2) kondisi madrasah, dibagi menjadi 3 komponen (a) profil pengelola madrasah; (b) profil madrasah negeri yang sederajat; dan (c) jarak madrasah negeri yang sederajat. (3) Kondisi tanah dan kepemilikan tanah; (4) luas tanah; (5) kondisi bangunan; (6) luas bangunan dan ruang; (7) sarana dan peralatan; (8) tenaga pendidik; (9) tenaga kependidikan; (10) tenaga pendukung; (11) siswa; (12) kurikulum; (13) prestasi; (14) dukungan, dibagi menjadi 2 bentuk (a) rekomendasi dari tokoh-tokoh dan organisasi masyarakat setempat, camat, dan bupati/wali kota, termasuk rekomendasi dari DPRD setempat; (b) bantuan yang pernah diberikan kepada masyarakat yang bersangkutan dari Pemda setempat. (15) Catatan lain, dalam bentuk informasi dan data.

Pelaksanaan kegiatan perubahan diselenggarakan melalui beberapa tahapan yaitu: pertama, pendataan madrasah negeri dan swasta yang didasarkan dari data pada Bagian Data dan Perencanaan (EMIS) Ditjen Pendidikan Islam. Kedua, penyusunan pedoman pelaksanaan kegiatan verifikasi penegerian dan penyempurnaan instrumen verifikasi. Ketiga, pengiriman edaran Direktur Pendidikan pada Madrasah kepada Kanwil Departemen Agama Up. Kabid Mapenda tentang pelaksanaan verifikasi penegerian madrasah. Keempat, penghimpunan data, bahan dan berkas persyaratan madrasah yang diusulkan oleh daerah/Kanwil setempat kepada Direktorat Pendidikan pada Madrasah. Kelima penilaian/ skoring kelengkapan data, bahan dan berkas yang diusulkan. Keenam verifikasi ke lokasi madrasah yang diusulkan untuk dinegerikan di daerah. Ketujuh melakukan rekapitulasi dan skoring instrumen verifikasi. Kedelapan koordinasi dengan Bagian Ortala Ditjen Pendidikan Islam dan Biro Organisasi dan Tatalaksana Setjen Departemen Agama. Kesembilan, penetapan calon madrasah negeri (Direktorat Jenderal Pendidikan Islam, 2007: 8). Jika dikaitkan dengan hasil penelitian ini kesesuaian terletak pada pengumpulan data yang berdasarkan persyaratan yang dibutuhkan. Dan Dirjen Pendidikan Madrasah melaksanakan verifikasi terkait kelengkapan persyaratan perubahan masing-masing madrasah yang mengikuti perubahan status.

Setelah calon madrasah yang akan dinegerikan sudah ditentukan. Dilanjutkan dengan kegiatan yang telah tertuang dalam Pedoman Pelaksanaan Kegiatan Penegerian Madrasah menurut Direktorat Jenderal Pendidikan Islam (2007: 8) sebagai berikut: (1) tim Asistensi berkoordinasi dengan pihak Kementerian Negara PAN terhadap usulan Departemen Agama tentang Penegerian Madrasah; (2) pengesahan Keputusan Menteri Agama tentang Pemberian Status Madrasah Negeri; (3) sosialisasi/ launching Keputusan Menteri Agama; (4) pengesahan SK. Bantuan Operasional dan Pemeliharaan (BOP) Madrasah yang dinegerikan; (5) pengiriman bantuan ke lokasi madrasah yang dinegerikan; dan (6) penyusunan laporan akhir kegiatan penegerian madrasah. Dari keenam kegiatan tersebut, yang relatif sama dengan hasil penelitian ini ada tiga yakni, yang pertama terbitnya Surat Keputusan status madrasah ini ditandai dengan pengesahan keputusan Menteri Agama. Kedua, sosialisasi/ launching status madrasah yang baru. Launching tersebut dilaksanakan setelah surat keputusan Menteri Agama diterbitkan. Ketiga, penugasan pemimpin baru dan 3 orang guru DPK oleh Kepala Kementerian Agama Kabupaten. 
Teori yang dikemukakan oleh Kasim (2004: 34) yang menjelaskan bahwa dalam proses perubahan terdapat empat tahap yaitu tahap inisiasi, tahap perencanaan, tahap pelaksanaan, dan tahap pembakuan. Jelas bahwa dari hasil temuan, perubahan status madrasah yang dilaksanakan MAN 2 Malang telah melakukan beberapa tahap tersebut. Pada tahap pelaksanaan disebutkan bahwa terdapat kegiatan pemantauan perubahan. MAN 2 Malang memantau perkembangan proses perubahan mulai dari proposal diajukan hingga surat keputusan diterbitkan. Selain itu pada tahap pembakuan terdapat kegiatan menyosialisasikan selesainya perubahan. Kegiatan sosialisasi dilaksanakan dalam bentuk launching penegerian sebagai bentuk peresmian status baru.

Perubahan pastinya memiliki seseorang yang berperan sebagai agen perubahan (agent of change). Agen perubahan harus mampu memulai, melaksanakan, dan mengelola perubahan. Supaya perubahan yang dilakukan mendapatkan hasil maksimal sesuai yang diharapkan. Agen perubahan bisa berasal dari dalam maupun luar organisasi. Di MAN 2 Malang yang berperan menjadi agen perubahan adalah pihak internal, yaitu kepala madrasah. Hal ini sesuai dengan pendapat Supriyanto (2009: 22) mengemukakan bahwa "orang atau pihak yang dapat menjadi agen perubahan dapat berasal dari dalam (agen internal) maupun luar organisasi (agen eksternal). Agen internal antara lain para manajer atau staf khusus dalam organisasi, sedangkan agen eksternal yaitu orang yang benar-benar ahli untuk memimpin perubahan organisasional pada bidang tertentu".

Menurut teori yang dikemukakan Supriyanto (2009: 41) menjelaskan bahwa "perjalanan proses perubahan tidak dapat berjalan secepat membalikkan telapak tangan, tetapi ia memerlukan waktu/ masa, kesempatan dan proses transisi". Temuan peneliti juga menunjukkan bahwa proses perubahan dilaksanakan dalam waktu yang relatif lama. Terhitung mulai dari pengajuan proposal pada tanggal 12 Februari 2007 hingga Surat Keputusan diterbitkan pada 6 Maret 2009.

\section{Penataan Status Madrasah Terhadap Guru dan Tenaga Kependidikan di MAN 2 Malang}

Perubahan yang terjadi pada organisasi juga berdampak pada perubahan sumber daya manusia yang ada di dalamnya. Perubahan status madrasah menjadi MAN 2 Malang membuat harapan para personel di dalamnya juga mengalami perubahan. Harapan para guru dan tenaga kependidikan yaitu agar MAN 2 Malang menjadi lebih baik lagi dan nasib guru dan karyawan lebih diperhatikan, dalam artian agar lebih sejahtera lagi. Harapan tersebut dapat terwujud apabila dilakukan upaya untuk mewujudkannya. Upaya yang dilakukan adalah dengan cara mengikuti pelatihan-pelatihan. Pelatihan tersebut dilakukan guru selain untuk mewujudkan harapan tersebut juga untuk meningkatkan ketrampilan dan pengembangan keilmuan guru. Dengan demikian intensitas pelatihan antara guru dan tenaga kependidikan jadi lebih sering. Hasil dari perubahan status madrasah tidak berdampak pada perubahan status guru maupun tenaga kependidikan. Status guru dan kependidikan tetap berstatus non PNS. Persepsi atau tanggapan yang ditimbulkan mengenai hal tersebut, guru dan tenaga kependidikan cenderung tidak mempermasalahkannya. Mereka tetap berlapang dada legowo menerima apapun status yang diberikan. Mereka menyadari bahwa perubahan yang dilakukan merupakan sebuah gerakan untuk meningkatkan efektivitas organisasi.

Dari hasil penelitian yang dilakukan dapat disimpulkan bahwa perubahan yang terjadi pada organisasi juga menyebabkan perubahan pada sumber daya manusia yang ada di dalamnya. Perubahan pada sumber daya manusia secara langsung dapat mempengaruhi perkembangan organisasi. Perubahan yang dirasakan oleh guru maupun tenaga kependidikan di MAN 2 Malang terjadi pada persepsi/ tanggapan, ketrampilan, dan harapan. Hal ini sesuai dengan kategori perubahan menurut Robbins (dalam Supriyanto, 2009: 24) perubahan pada manusia meliputi sikap, ketrampilan, harapan, persepsi, dan perilaku. Namun pada sikap dan perilaku tidak dijumpai perubahan.

Perubahan juga dialami oleh tenaga kependidikan. Yang awalnya dulu masih terdapat tenaga kependidikan yang berkualifikasi SMA, sekarang sudah berubah menjadi S1. Perubahan tersebut atas dorongan kepala madrasah yang mewajibkan tenaga kependidikan untuk bersekolah lagi. Kebijakan kepala madrasah tersebut agar tenaga kependidikan bekerja sesuai dengan fak-nya atau spesifikasi pada bidangnya. Selain itu agar dari segi keilmuan lebih dapat diperhitungkan. Temuan ini sesuai dengan Peraturan Menteri Pendidikan Nasional Nomor 24 Tahun 2008 tentang Standar Tenaga Administrasi 
Sekolah/Madrasah menyatakan bahwa tenaga administrasi sekolah/madrasah terdiri atas kepala tenaga administrasi sekolah/madrasah, pelaksana urusan, dan petugas layanan khusus. Dari peraturan tersebut diketahui bahwa pelaksana urusan untuk SMA sederajat harus berkualifikasi minimal SMA/MA/SMK/ MAK.

\section{Penataan Sarana dan Prasarana Setelah Menjadi MAN 2 Malang}

Berdasarkan temuan yang diperoleh dari hasil penelitian ini bahwa semua aset yang dimiliki oleh madrasah akan dialih statuskan menjadi milik negara. Pengelolaan aset, tenaga, siswa, dan proses pembelajaran semua menjadi tanggung jawab Kementerian Agama. Begitu juga dengan lokasi yang ditempati MAN 2 Malang yang merupakan hasil wakaf dari masyarakat. Status tanah memang dimiliki oleh negara tetapi penyebutannya tetap hasil wakaf. Tanah wakaf digunakan hanya untuk kepentingan masyarakat. Sama halnya menurut Peraturan Pemerintah Republik Indonesia nomor 42 tahun 2006 tentang pelaksanaan undang-undang nomor 41 tahun 2004 tentang wakaf, wakaf adalah "perbuatan hukum Wakif untuk memisahkan dan/atau menyerahkan sebagian harta benda miliknya untuk dimanfaatkan selamanya atau untuk jangka waktu tertentu. Sesuai dengan kepentingannya guna keperluan ibadah dan/atau kesejahteraan umum menurut syariah".

Prosedur dalam mewakafkan tanah menurut Kementerian Agama Kabupaten Banjarnegara (2016) yaitu sebagai berikut: (a) sebuah Keluarga bermusyawarah terlebih dahulu untuk mewakafkan tanah yang dimilikinya; (b) Wakif bersama Nazhir mempersiapkan segala persyaratan administrasi sertifikasi tanah wakaf; (c) Kepala keluarga (selaku Wakif), bersama dengan Nazhir (Pengurus wakaf) dan saksi datang ke Kantor Urusan Agama (KUA) menghadap Kepala KUA selaku Pejabat Pembuat Akta Ikrar Wakaf (PPAIW); (d) PPAIW memeriksa persyaratan wakaf dan dilanjutkan pengesahan Nazhir; (e) Wakif mengucapkan ikrar wakaf di hadapan PPAIW dan saksi-saksi, selanjutnya membuat Akta Ikrar Wakaf (AIW) dan salinannya; (f) Wakif, Nazhir dan saksi pulang dengan membawa AIW; (g) PPAIW atas nama Nazhir menuju ke Kantor Pertanahan Kabupaten/Kota dengan membawa berkas permohonan pendaftaran tanah wakaf dengan pengantar; (h) Kantor Pertanahan memroses sertifikat tanah wakaf; (i) Kepala Kantor Pertanahan menyerahkan sertifikat tanah wakaf kepada Nazhir, kemudian ditunjukkan kepada PPAIW untuk dicatat pada daftar Akta Ikrar Wakaf. Hasil temuan penelitian ini menjelaskan bahwa proses penyerahan aset berupa tanah wakaf ke pemerintah dimulai dengan Wakif menemui Kepala madrasah untuk mewakafkan tanah yang dimilikinya. Penyerahan wakaf dilakukan ketika madrasah sudah berstatus negeri. Beberapa minggu setelahnya kepala madrasah menghubungi Kementerian Agama untuk meminta pertimbangan. Kemudian pihak Kementerian Agama menyetujui dan langsung datang bersama pihak KUA dengan membawa surat AIW.

Setiap perubahan pastinya terdapat kendala atau penghambat dalam pelaksanaannya. Kendala yang dialami oleh madrasah dalam perubahan lokasi yaitu saat dalam tahap pembangunan gedung baru terdapat pemborong bangunan yang tidak bertanggungjawab dalam menyelesaikan gedung madrasah. Akibatnya proses pembangunan gedung baru sempat terhenti. Sesuai yang dikatakan oleh Supriyanto (2009: 62) bahwa "hampir setiap perubahan organisasional selalu diikuti pendukung dan penghambatnya".

\section{Dampak Perubahan Status Madrasah Setelah Menjadi MAN 2 Malang}

Perubahan selain dapat menimbulkan dampak positif juga menimbulkan dampak negatif bagi organisasi Winardi (dalam Sugandi, 2013: 315). Temuan dari penelitian ini menunjukkan bahwa perubahan berdampak positif maupun negatif. Dampak positif dirasakan oleh banyak pihak di antaranya: (a) bagi madrasah, semakin bertambahnya peserta didik, sarana dan prasarana, dan madrasah semakin dikenal oleh masyarakat; (b) bagi guru, bertambahnya pengalaman dan wawasan guru dalam mengajar; (c) bagi siswa, prestasi siswa lebih meningkat. Selain itu siswa merasa bangga karena bersekolah di madrasah negeri; (d) pengurus, meringankan beban yayasan dari segi finansial, tidak merasa khawatir akan matinya madrasah swasta, dan hilangnya tanggungjawab terhadap Wakif; dan (e) masyarakat, perekonomian menjadi lebih meningkat. Peningkatan tersebut dikarenakan adanya toko dan pondok pesantren yang semakin berkembang. Sedangkan dampak negatif dari perubahan status adalah secara finansial pengurus merasa kehilangan atas kepemilikan sarana dan prasarana yang diambil alih oleh 
pemerintah. Dilain sisi pengurus juga merasa diuntungkan karena madrasah menjadi lebih berkembang. Selain itu dampak yang dialami pengurus yaitu setelah madrasah berubah menjadi negeri jabatan yang diemban oleh pengurus otomatis juga hilang. Setelah menjadi negeri jabatan pengurus berubah menjadi komite madrasah.

\section{KESIMPULAN}

Pelaksanaan perubahan status madrasah merupakan inisiatif dari dewan guru, pengurus, komite, dan juga tokoh masyarakat. Alasan perubahan status madrasah tersebut meliputi, pertama karena di wilayah Kecamatan Turen belum ada madrasah aliyah yang berstatus negeri. Kedua, meningkatkan daya saing antar sekolah di Kecamatan Turen. Dan ketiga, finansial madrasah yang kurang memadai. Tujuan pelaksanaan perubahan status yaitu agar madrasah lebih maju, terus berkembang dan tetap hidup dan menjadi madrasah yang lebih baik dari tahun-tahun sebelumnya.

Proses pelaksanaan perubahan status madrasah pertama perencanaan yaitu dimulai dari madrasah mendapatkan informasi mengenai perubahan status madrasah. Informasi tersebut kemudian oleh kepala madrasah ditindaklanjuti dengan mengadakan rapat. Kedua, pelaksanaan, dalam menyiapkan segala keperluan perubahan berdasarkan ketentuan atau kriteria yang telah ditetapkan oleh pemerintah. Langkah selanjutnya yaitu, data yang sudah dipersiapkan disusun dalam bentuk proposal dilanjutkan dengan diajukan kepada Kementerian Agama di tingkat Kabupaten, Provinsi dan Direktorat Jenderal Pendidikan Madrasah. Langkah ketiga, Direktorat Jenderal Pendidikan Madrasah membentuk tim khusus untuk melaksanakan verifikasi ke madrasah yang berminat mengikuti perubahan status. Ketiga, selama pengajuan proposal sampai surat keputusan terbit, madrasah selalu memantau proses perkembangannya. Dan terakhir pembakuan, madrasah melaksanakan launching penegerian, mengubah stempel dan kop surat menyurat dan mengganti papan nama sekolah, penunjukan kepala madrasah baru dan memperoleh 3 orang guru DPK oleh Kepala Kementerian Agama Kabupaten.

Perubahan yang terjadi pada madrasah juga berdampak pada perubahan sumber daya manusia yang ada di dalamnya. Perubahan yang terjadi pada guru yaitu intensitas pelatihan dilaksanakan lebih tinggi dan SK tugas guru. Perubahan yang dialami oleh tenaga kependidikan yaitu, pertama terdapat tenaga kependidikan yang sebelumnya berkualifikasi SMA sekarang sudah cukup banyak yang meraih level S1. Kedua, sebagian berganti profesi menjadi guru. Ketiga, intensitas pelatihan menjadi lebih tinggi.

Perubahan pada segi sarana dan prasarana lebih dirasakan pada pasca perubahan lokasi madrasah. Pindahnya lokasi madrasah dikarenakan luas lahan yang terlalu sempit. Madrasah memerlukan lokasi yang luas untuk menunjang perkembangan pembangunan madrasah. Lokasi yang ditempati oleh madrasah merupakan hasil wakaf dari warga masyarakat. Gedung yang sebelumnya ditempati oleh MIPN Miftahul Huda Turen.

Dampak dari perubahan status madrasah di MAN 2 Malang berdampak positif dan negatif. Dampak positif dapat dirasakan oleh berbagai pihak yaitu, madrasah, guru, siswa (alumni), pengurus, dan masyarakat. Dampak negatif dari perubahan status madrasah di MAN 2 Malang yaitu secara finansial pengurus merasa kehilangan karena kepemilikan sarana dan prasarana diambil alih oleh pemerintah.

\section{DAFTAR RUJUKAN}

Direktorat Jenderal Pendidikan Islam. 2007. Pedoman Kegiatan Pelaksanaan Penegerian Madrasah. Jakarta. Kasim, I. 2004. Manajemen Perubahan. Bandung: Penerbit Alfabeta.

Kementerian Agama Kabupaten Banjarnegara. 2016. Syarat, Proses dan Prosedur Sertifikasi Tanah Wakaf. (Online), (http://banjarnegara.kemenag.go.id/berita/read/syarat-proses-dan-prosedur-sertifikasi-tanah-wakaf), diakses pada 25 April 2018.

Peraturan Menteri Agama Republik Indonesia Nomor 14 Tahun 2014 tentang Pendirian Madrasah yang Diselenggarakan oleh Pemerintah dan Penegerian Madrasah yang Diselenggarakan oleh Masyarakat. (Online), (https://babel.kemenag.go.id/files/babel/ file/file/PMA/zshm1405397069.pdf), diakses pada 16 Februari 2017. 
Peraturan Menteri Pendidikan Nasional Republik Indonesia Nomor 24 Tahun 2008 tentang Standar Tenaga Administrasi Sekolah/Madrasah. (Online), (http://bsnp-indonesia.org/ id/wp-content/uploads/tenaga/ Permen_24_Th-2008.pdf), diakses pada 23 April 2018.

Peraturan Pemerintah Republik Indonesia Nomor 42 Tahun 2006 tentang Pelaksanaan Undang-undang Nomor 41 Tahun 2004 tentang wakaf. (Online), (https://kemenag. go.id/file/dokumen/ PP422006.pdf), diakses pada 24 April 2018.

Sugandi, L. 2013. Dampak Implementasi Change Management pada Organisasi. Jurnal ComTech. (Online), 4 (1), (http://journal.binus.ac.id/index.php/ comtech/article/view File/2743/2145), diakses pada 23 April 2018.

Supriyanto, A. 2009. Manajemen Perubahan: Bahan Ajar Berbasis Benchmarking. Malang: Fakultas Ilmu Pendidikan Universitas Negeri Malang.

Undang-Undang Nomor 20 Tahun 2003 tentang Sistem pendidikan Nasional. (Online), (http:// sindikker.dikti. go.id/dok/UU/UU20-2003-Sisdiknas.pdf), diakses pada 31 Maret 2017.

Winardi, J. 2005. Manajemen Perubahan (Management of Change). Jakarta: Kencana. 